\title{
Transitions and Diversity in Didactics: An Exploration Searching for Implications for Vocational Education and Training
}

\author{
Lázaro Moreno Herrera \\ Department of Education \\ Stockholm University \\ SE 10691 Stockholm, Sweden \\ E-mail: Larazo.moreno@edu.su.se
}

Received: 28 October 2015; Accepted: 10 December 2015; Published online: 15 December 2015

\begin{abstract}
Depending on the perspective and even language, the concept of didactics is defined in different ways. The debate about conceptualization, particularly concerning the equivalence in English of what in other languages, specifically Germanic and Latin languages, is termed 'didactics', is well documented in the research literature. There is a claim in this article concerning the need to transcend the language discussion; it is indeed necessary, especially for Vocational Education \& training (VET), to develop a close linkage between what some authors consider "an empirically based" side of didactics associated with empirical findings and the "non-empirical" side that is associated with theoretical constructs for understanding the teaching-learning process.

The main aim of this article is to revisit research in didactics in German, Nordic and French contexts looking for diversity in the various approaches. This is intended to contribute to the discussion about prospects and shortcomings in the development of a didactics for the intricate subject of vocational education and training. Rather than alternative didactical paths, the article intends to suggest lines of development, encourage discussions and the further research needed concerning relationship didactics and vocational education and training.
\end{abstract}

Keywords: Didactics, Teaching and Learning, Vocational Education and Training, Educational Contexts

\section{Bibliographical notes:}

Dr Lázaro Moreno Herrera is a Professor of Education with specialization in Vocational Education \& Training at the Department of Education at Stockholm University, Sweden where he leads the research group in the field. He has a PhD in Technology Education from Åbo Academy University, Finland. His research interests covers a variety of research areas within vocational education, including didactics, policy issues and comparative analysis. 


\section{Introduction}

Earlier studies, such as the one by Klaus Hoffmann (c.f. 1996, p. 95), indicate that the literature on didactic models offers "a confused profusion of planning strategies, and especially the beginning teachers are faced with a considerable classroom dilemma". Moreover, Hoffmann argues, "there is hardly any sufficiently well-founded theory of teaching on the basis of which specific and individual instructional models of practice and action could be substantiated, transferred and integrated". This claim, with further arguments, is to be found in successive research particularly in what can be called the German and Nordic tradition of didactics (e.g. Kansanen 2009; Meyer 2010; Uljens 1997a,b). Especially interesting in this context is the proposal of the so-called "design for learning" by Staffan Selander (e.g. 2008), which might bridge the more traditional notion of didactics in the Germanic and Nordic context with the Anglo-Saxon curriculum theory tradition. In the subject/area of vocational education and training (VET), participants involved in the learning process are systematically challenged by a complex and multidimensional variation in context with demands for an innovative approach to didactics.

Depending on the perspective and even language, the concept of didactics is defined in different ways. The debate about conceptualization, in particular concerning the equivalence in English of what in Germanic and Latin languages is termed 'didactics', is well documented in the research literature (e.g. Westbury, Hoppmann and Riquarts 2000).

This article intends to revisit some influential didactical works both from German, Nordic and French contexts looking for transitions and diversities in approaches to didactics. Contributions from research on didactic in the French context are here presented because of the significant influence that this research has had in Scandinavia and particularly in the Swedish discussion of didactics (c.f. Carlgren 2015).

There is no ambition to survey in the space of this article the extensive volume of research on didactics available, neither propose alternative to approaches. The intention is rather to suggest lines of development, encourage discussions and further the research that this theme requires. Exploratory in character as it intends to be, this article tries to identify potential paths for the development of research on didactics in the complex area of vocational education and training, if this is finally considered a viable enterprise.

\section{Didactics - A needed conceptualization}

Many controversies are visible in the different ways that didactics has been conceptualized (c.f. Hudson and Meyer 2011; Klingberg 1972; Uljens 1997b). Interesting for the subject matter of this article is the analysis by Stefan Hopmann (2006) on the traditional path of didactics' development and how it has influenced the design of specific didactic strategies in different subjects. Hopmann traces the origin of 'Didaktik' back to the ideas of students' activity (Socrates), in a disciplinary setting (Hugh of Saint Victor), with a certain order of knowledge (Thomas Aquinas) and a necessary choice of subject matter (Comenius). He adds that in the German context, 'Didaktik', in its different forms, can be described as a systematic reflection of how to organise teaching in a way that brings about the individual growth of the student. This means, accordingly, that subject matters can open up different educative meanings for learners, and thus that teaching and 
learning follow different paths. 'Didaktik' as presented is very different from a curriculum perspective where subject matter and meaning have to be close, and also from the French tradition of 'transposition didactique', which is interested in differences between meanings and subject matter in order to enable the learning of the appropriate meanings of such matter.

Hopmann (2006) argues that the search for a common core of Didaktik has been a continuous endeavour, since there are "innumerable variations available for every purpose and taste", as presented below.

Table I. Modes of 'Didaktik' (Hopmann 2006, p. 114)

\begin{tabular}{|l|l|l|l|l|l|}
\hline \multicolumn{5}{|c|}{ Foundations } & Modes of Didaktik \\
\hline Reference & $\begin{array}{l}\text { Methodo- } \\
\text { logical }\end{array}$ & Institutions & Normative & Clients & Actions \\
\hline $\begin{array}{l}\text { Philoso- } \\
\text { phical }\end{array}$ & Hermeneutical & Catholic & Nursery & Children & Education \\
\hline $\begin{array}{l}\text { Anthropo- } \\
\text { logical }\end{array}$ & $\begin{array}{l}\text { Phenomenolo- } \\
\text { gical }\end{array}$ & Jewish & School & Adults & Instruction \\
\hline $\begin{array}{l}\text { Psycho- } \\
\text { logical }\end{array}$ & Experimental & Marxist & University & $\begin{array}{l}\text { Handi- } \\
\text { capped }\end{array}$ & Training \\
\hline $\begin{array}{l}\text { Sociolo- } \\
\text { gical }\end{array}$ & Empirical & Ecological & Company & Parents & Teaching \\
\hline $\begin{array}{l}\text { Educa- } \\
\text { tional }\end{array}$ & Constructivist & Humanistic & Prison & Minority & Playing \\
\hline Etc. & Etc. & Etc. & Etc. & Etc. & Etc. \\
\hline
\end{tabular}

Combining any two of these examples leads us to "the core of at least one existing school of Didaktik" (Hopmann 2006, p. 114). Hopmann would, however, make the distinction that in spite of this seemingly unlimited variety of scopes most of these modes of 'Didaktik' share the same common places to describe what didactics is about, namely: (a) the concept of 'Bildung', (b) the embedded differentiation of matter and meaning, and (c) a concept of the necessary autonomy of teaching. This thus continues the above-mentioned problems of order, sequence and choice within their respective frames of reference.

\section{Anthropological Theory of Didactics (ATD), didactic transposition and Joint Action Theory in Didactics (JATD)}

Contributions from French research on didactics, and in particular the 'transposition didactique' (didactic transposition in the following) (Chevallard 1982), are particularly valuable for an analysis and a discussion of the possible significance of didactic research for vocational education and training. Didactic transposition is part of what has come to be known as the Anthropological Theory of Didactics (ATD) (c.f. Chevallard 2006). ATD, it is argued, dismisses - based on both fact and theory - some widespread views of teaching and learning. It tries to develop a new attitude towards 'the didactic', seen as an anthropological dimension of social life. ATD emphasises the logic behind the evolution of a 'science of the didactic' that, in adapting to the changing nature of its object of study, currently brings new ideas to the fore.

The idea of a didactic transposition of scholarly knowledge was adapted and elaborated by Chevallard from the sociologist Michel Verret (1975), who 
emphasised that knowledge can not be taught in the way it was produced in the scientific community: the 'transmission didactique' induces a selection as it privileges the success, continuity, and synthesis of knowledge, not typical characteristics of the production of knowledge (pp. 140-141). Due to the separation of subjects in teaching institutions, and the need for evaluation, a didactic transposition process is defined by decomposition, depersonalisation and the development of a detailed teaching sequence of knowledge (pp. 146-147). Chevallard uses these three notions. The process of transposition presupposes that the knowledge to be taught is clearly defined and open to social control.

The concept of didactic transposition has become widely used in educational sciences and especially in various educational disciplines. Reviewing earlier research, Perrenoud (1998) argues that it is relevant to consider four relevant aspects as illustrated in the following.

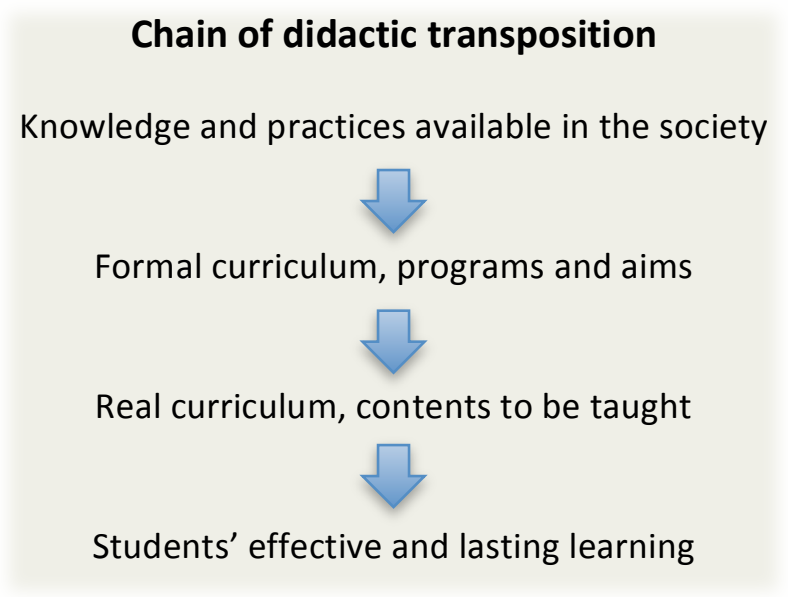

Figure 1. Chain of didactic transposition (modified after Perrenoud, 1998, p. 487)

Perrenoud (1998) explains the figure as follows: the first arrow indicates the transformation of knowledge and practices in curriculum, also called the formal or prescribed curriculum. This is what Chevallard calls external didactic transposition. The second arrow indicates the transformation or content of the programs designed at school by the teacher, an internal implementation, which is largely a margin of interpretation or creative teachers. Perrenoud cites Chevallard to argue that the chain is limited to the path of knowledge from the state of 'scholarly knowledge' to a state of 'knowledge to be taught' (external transposition), thence from the state of 'knowledge to be taught' to 'knowledge taught' (internal implementation). The third arrow is considered to indicate the process of learning, ownership, construction of knowledge and skills in the minds of students.

According to Perrenoud (1998), this is undoubtedly a new and decisive step in the path of knowledge and culture. However, he questions whether or not to include this last step in the process of didactic transposition itself. From a period in which the notion of transposition has been used primarily in disciplines where academic knowledge has central role, there is still much to be done in other subjects in order to broaden the transposition theory on didactics. Vocational 
Education and Training is an area in which empirical research on didactic transposition might be valuable given the complexities of contents and learning environments. A broader conceptualization of the implementation will provide didactics for vocational education and training with a considerable number of new lines of development.

Criticisms to a false symmetry, when it is suggested that knowledge and practice are two equivalent sources of didactic transposition, are most valuable for our area of concern (vocational education).

Practices mobilize knowledge, but does not reduce it, even if, next to academic knowledge, knowledge experts, professionals or practitioners. The limits of the dissociation between knowledge and practice lead me to introduce the concept of skills and to offer a more complex mapping of the chain of transposition. (Perrenoud 1998, p. 447 , my translation)

The work of the French didactician Gerard Sensevy (c.f. 2011; 2012) in developing the so-called Joint Action Theory of Didactics (JATD), has been influential in the discussion on didactics in the Nordic context and Sweden in particular (c.f. Carlgren 2015). The JATD places an emphasis on the 'actional turn' that didactics enacts. The point is not only to consider in a separate way the teacher's or the student's action, but the structure and function of the knowledge at stake (Sensevy 2012). Beyond that, the JATD institutes a specific unit of analysis, which Sensevy calls epistemic joint act. The linguistic criterion of the description of such an epistemic joint act is that it is impossible to describe it without at the same time describing the teacher's action, the student's action, and the way these two actions enact a specific move toward the knowledge at stake. As occurs often in the JATD, this assertion is a very general and anthropological one. For example, if a parent holds her hands out to a young child who is learning to walk, as an incentive to make him or her walk towards those hands, while the young child tries to take some steps to reach them, this is an epistemic joint act. One cannot understand each behaviour (parent/teacher or child/student) without taking into account the joint process and the knowledge (walking) that gives its form to the enacted gestures (Sensevy 2012, pp. 504-505).

Discussions concerning the possible contributions of JATD are emerging in different academic forums within the VET field in the Nordic countries, and there seems to be a keen interest in exploring its use in different learning contexts in VET. Nevertheless, systemic research is at present scarce but much needed.

\section{$4 \quad$ Permanent didactic challenges}

An interesting analysis of the role of didactics in bridging learning and sustainable development is presented in a study by Andreas Fischer (2006). This study is of particular interest when discussing the potentialities of a specific didactics for vocational education is the subject matter. Fischer (2006, p. 4-5) uses the concept "sustainable learning worlds" to argue that the discussion about sustainability includes a change in the content, and furthermore concerns the way of structuring time, the participatory shaping of complex teaching-learning arrangements as well as a performance evaluation. According to his line of argumentation: 
"...the characteristic feature of a new learning culture is to overcome the linear and mechanistic didactic reduction of the complex reality to clearly structured chains of cause and effect - with the aid of complex teaching-learning arrangements and with the aim of linking productand process-oriented learning. The self-regulation of learning and the metacognition have to be strengthened; on the whole, the responsibility of learning has to be gradually transferred to the students; this also includes the self-assessment." (p. 4)

Continuing the analysis further, Fischer (2006) coincides with other studies in didactics in the Nordic countries (e.g. Uljens 1997a; Wenerstam and Hansen, 2006), and makes a claim about the need to move from lineal strategies in didactical formulation and instead provide room for openness, error probability, fault liability, interaction, systems dynamics and self-organisation. This is meant to be a direction different from...

"...the so called teaching-learning short circuit that says that all available knowledge also has to be taught, and that everything that is taught also has to be learnt as well as those myths that nurture the believe in the feasibility of learning processes, and harbour the illusion that educational success guarantees a successful (professional) life have to be questioned." (Fischer 2006, p. 4)

Furthermore, this is seen as a shift of attention away from mere instruction to arrangements that facilitate learning - as competences cannot be taught (Fischer 2006). From this perspective the teacher is then expected to assume the task of creating learning events, offering information and shaping the learning in a way that the learners are able and required to build their knowledge in action-learning situations. The aim here is a paradigm change, away from an instruction-oriented educational process to one that promotes more autonomous learning.

In developing the notion of "sustainable learning worlds", the starting question is formulated as follows: "How can an educational process oriented to the idea of sustainability be created that besides specialised knowledge (disciplineoriented) highlights integrated (interdisciplinary) working, and at the same time promotes self-organised learning?" (Fischer 2006, p. 5). Accordingly, it is possible to confront the students with complex issues along sustainability-oriented complex teaching-learning arrangements. In such learning worlds, according to Fischer, sustainable working and/or business processes could be simulated. These at the same time seem to be the appropriate place to create and test participatory, actionoriented methods. In line with research on didactics and learning (c.f. Ghaye 2010; Janik and Kansanen 2009; Meyer 2010), this is associated with an approach where learning is understood as an active, self-directed, constructive and cooperative process.

"Such an interdisciplinary, problem-oriented teaching-learning corresponds to the intention of integrated learning, and therefore meets the requirements of an education in which the self-organisation, reflection and personal responsibility of the individual is in the centre of attention." (Fischer 2006, p. 5) 


\section{Concluding remarks - A didactic for Vocational Education \& training, utopia or achievable?}

Consequently, with the line of argumentation followed in this article, I would like to argue that beyond transcending the language discussion there is indeed a need, particularly relevant for VET, to develop a close linkage between what some authors consider "an empirically based" side of didactics associated with empirical findings and the "non-empirical" side associated with theoretical constructs for understanding the teaching-learning process (e.g. Wenerstam and Hansen 2006).

There is a coincidence in the claims of earlier studies (c.f. Larsson 2006; Taylor 1997; 2000) in referring to the problem of the relationship between theory and empiricism in the specific context of research on didactics. This is mainly related to the argument that didactic theory does not develop in interaction with empirical data. Larsson (2006, p. 145) plainly refers to the tendency that researchers seldom develop a theoretical justification of education and then continue developing it by examining when it is implemented 'in reality'. The academic debate becomes the key point instead, and a more collaborative work to examine important questions empirically remains missing. Equally important are examples of extensive relevant empirical research not used for the further development of theories. What does this all say to us VET researchers interested in the complexity of learning processes in different environments?

Returning to the key question of this article, I would like to claim that there are indeed arguments to continue discussing the implications of different didactical approaches for the development of vocational knowledge. As suggested by contributions from the didactic transposition approach, there is a great need to continue developing the basis of a didactics that will be encompassing and dynamic enough to address the complex and varied situation of guidance concerning the learning process in the VET field. In addition to the variety of contexts, it is equally significant to consider the complexity derived from the various interacting components of the teaching and learning process.

More is to be done in creating or continuing to develop a didactics that encompasses the complexities of VET considering its different levels and different settings. Whether we will call it didactics for VET or something else is not the key issue. As confessed at start this article, the intention here is just to contribute to the discussion and encourage the further, still needed research. If this is the case the aims of this article will be considered accomplished! 


\section{References}

Carlgren, I. (2015). Kunskapskulturer och undervisningspraktiker. Göteborg: Daidalos.

Chevallard, Y. (1982). Pourquoi la transposition didactique? Séminaire de didactique et de pédagogie des mathématiques: Actes de l'année 1981-1982 (pp. 167-194). Université scientifique et médicale de Grenoble: IMAG.

Chevallard, Y. (2006). Readjusting Didactics to a Changing Epistemology. European Educational Research Journal, 6(2), 131-134.

Fischer, A. (2006). Learning and sustainability: correlations, challenges, concrete ideas from the point of view of vocational education and economy. Paper presented at the 25th International Course on vocational Training and Education in Agriculture, August 2006.

Ghaye, T. (2010). Teaching and Learning Through Reflective Practice. London: Routledge.

Hoffmann, K. (1996). The dilemma of didactic paradigms and the practitioner's challenges in integrative planning. Hacettepe Üniversitesi Ĕgitim Fakültesi Dergisi (Journal of Education Haceteppe University), 12(12), 95-99.

Hopmann, S. (2006). Restrained Teaching: The common core of Didaktik. European Educational Research Journal, 6(2), 109-124.

Hudson, B., \& Meyer, M A. (2011). Beyond Fragmentation Didactics, Learning and Teaching in Europe. Leverkusen: Barbara Budrich.

Janik, T., \& Kansanen, P. (Eds.).(2009). Studies on teaching and learning in different school subjects. Orbis Scholae, 3(2).

Hopmann, S. (1997). Wolfgang Klafki och den tyska didaktiken. In M. Uljens (Ed.), Didaktik teori, reflektion och praktik. Lund: Student-litteratur.

Hopmann, S. (2000). Klafki's model of didaktik analysis and lesson. In I. Westbury, S. Hopmann, \& K. Riquarts (Eds.), Teaching as a reflective practice: The German didaktiktradition (pp. 197-206). London: Erlbaum.

Kansanen, P. (2009). The curious affair of pedagogical content knowledge. Orbis Scholae, 3(2), 5-18.

Kansanen, P. (2009). Subject-matter didactics as a central knowledge base for teachers, or should it be called pedagogical content knowledge? Pedagogy, Culture \& Society, 17(1), 29-39.

Klingberg, L. (1972). Introducción a la didáctica general. Havana: Editorial Pueblo y Educación.

Larsson, S. (2006). Didaktik för vuxna lärande - tankelinjer $i$ internationell litteratur. Stockholm: Vetenskaprådet.

Meyer, M A. (2010). A view on didactics and instructional planning from the perspective of research on learner development and educational experience. Education \& Didactique, 4(2), 75-99.

Nijhof W. J., Heikkinen A., \& Nieuwenhuis L. (2002). Shaping flexibility in vocational education and training: institutional. The Netherlands: Kluwer Academic Publishers.

Perrenoud, P. (1998). La transposition didactique à partir de pratiques: des savoirs aux compétences. Revue des sciences de l'éducation, XXIV(3), 487-514.

Sensevy, G. (2011). Le Sens du Savoir. Eléments pour une théorie de l'action conjointe en didactique. Louvain-la-Neuve: De Boeck.

Sensevy, G. (2012). About the Joint Action Theory in Didactics. Zeitschrift für Erziehungswissenschaft, 15(3), 503-516. 
Sorensen, C. (2005). Learning by leaving: placements abroad as a didactic tool in the context of vocational education and training in Europe. Luxembourg: Office for Official Publications of the European Communities.

Taylor, E.W. (1997). Building Upon the Theoretical Debate: A Critical Review of the Empirical Studies of Mezirow's Transformative Learning Theory. Adult Education Quarterly, 48(1), 34-59.

Taylor, E. W. (2000). Analyzing research on Transformative Learning Theory. In Mezirow, J., \& Associates (2000), Learning as Transformation. Critical Perspectives on a Theory in Progress (pp. 285-328). San Fransisco: Jossey Bass.

Uljens, M. (1997a). School didactics and learning. Hove, East Sussex: Psychology Press.

Uljens, M. (1997b). European Identity in Change - The meeting between Russian, German and Nordic Educational Traditions (Report no 10). Vasa: Åbo Akademi University, Department of Education.

Verret, M. (1975). Le temps des études. París: Honoré-Champion.

Wenerstam, C.-G., \& Hansen, S. (2006). Models of Didaktik in classrooms, implications for practice. Vasa: Åbo Akademi.

Westbury I., Hopmann S., \& Riquarts K. (Eds.).(2000). Teaching as a reflective practice. The German didaktik tradition. London: Erlbaum. 